\title{
Eight Years After The Fact Is SOX Working? A Look At The Brooke Corporation
}

Beth Hazels, Rockhurst University, USA

\begin{abstract}
In 2002 the Sarbanes-Oxley Act (SOX) was passed; in addition, federal sentencing guidelines have been revamped and the Securities Exchange Act of 1934 has been brushed off, all in an attempt to codify the ethical behavior of companies, their executives, and their management. The goal was to make companies and employees behave ethically; however, whether that has worked or not is questionable. Many argue that the implementation and ongoing requirements of Sarbanes Oxley and other laws are costly, time consuming, and as yet ineffective. Recent evidence suggests that for some organizations these requirements and the associated punishments are not a sufficient deterrent. In many instances law has at best led to a culture of compliance rather than a culture of integrity. Even more disappointing is that too often the very activities Sarbanes Oxley was designed to prevent continue to slip past regulators until it is too late and the damage incurred. Brooke Corporation is one example where these laws have seemingly failed. With this in mind, this paper will attempt to: 1) provide examples from the Brooke Corporation that demonstrate the evolving culture of compliance vs. one of true integrity, 2) identify areas where the law continues to compete with long-standing corporate culture, 3) discuss those areas where additional work remains for Sarbanes Oxley to achieve its intended impact, and 4) discuss what work remains to be done to make other laws effective.
\end{abstract}

Keywords: SOX, Ethics, Management, Sarbanes Oxley, Securities Exchange Act 1934, Federal Sentencing Guidelines

\section{HISTORY OF THE COMPANY}

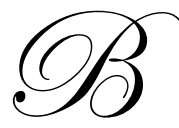

rooke Corporation was once one of the largest franchisors of property and casualty insurance in the United States selling insurance and other products through its franchisee locations in Kansas, Oklahoma, California and several other states. In 1996, Brooke adopted a franchise approach to aid in the expansion of its business (Margolies, 2009, January 10).

Brooke Corporation (Brooke), and its subsidiaries, was founded by Robert Orr in 1986. The company began in Phillipsburg Kansas and moved to Overland Park Kansas in 1996 (Dornbrook, 2008, October 10). Robert Orr played a key role in management of the company. He held several key roles in the parent company and its subsidiaries. Most recently he was Director and chief finance officer of Aleritas, and Chairman of the Board and CEO of Brooke Capital and Chairman of the Board at Brooke Corporation. Robert's brother, Leland Orr, was also active in senior management of Brooke. He acted as a director and officer since the inception of Brooke. In addition, Robert Orr's nephew, Mick Lowry was the President of Aleritas.

Brooke Corporation's main business was to sell insurance and related services through franchises (Fidler, 2008, October, 31). This was supported through several subsidiaries and affiliates. Brooke Agency Services LLC (BASC LLC), formerly Brooke Franchise, dealt with the sales of insurance and other products through franchisees (McGraw-Hill Companies, Inc., 2009). Aleritas Capital Corporation (Aleritas), formerly known as Brooke Credit Corporation, provided lending services to franchisees (WorldScope, 2009). Brooke Brokerage sold insurance on a 
wholesale basis (Margolies, 2009, January10). Brooke Capital Advisors was an insurance consulting agency providing, among other services, business valuation services to individuals interested in selling their insurance business. Brooke Savings Bank, formerly Generation Bank, provided retail banking services (McGraw-Hill Companies, Inc., 2009). In August 2007, Brooke Capital was approved for listing on the AMEX under BCP. Brooke Corporation itself was listed on the NASDAQ in October 2008 under BXXX (Everitt, 2007).

The financial demise of Brooke Corporation and its' subsidiaries started in 2008 and is continuing as bankruptcy proceedings and the resolution of several lawsuits continue. As the company began to falter it became embroiled in several lawsuits, starting with a lawsuit filed by Bank of New York. As a result of the lawsuits, a downturn in credit markets and other issues Brooke Corporation and Brooke Capital filed for bankruptcy. In October 2008, Brooke Corporation and Brooke Capital filed for Chapter 11 protection while Aleritas avoided bankruptcy (Fidler, 2008, October, 31). By November, 2008 Brooke Investments filed bankruptcy (Fidler, 2008, October, 31). Albert Reiderer was named as Special Master in the lawsuit (Fidler, 2008, October, 31). Attempts were made to save the company, but those attempts failed. Trading of the stock was stopped in October 2008 (“Trading halted," 2007) and Mr. Orr filed personal bankruptcy in December 2008(“Brooke Corp. trustee," 2009).

\section{BROOKE - A CULTURE OF COMPLIANCE VERSUS INTEGRITY}

The laws as they exist today create a corporate environment focused on compliance instead of integrity. In her book Cases In Leadership, Ethics and Organizational Integrity (1997) Lynne Sharp Paine states that "organizational factors play a critical role in fostering - or in discouraging - responsible behavior on the job" (Sharp-Paine, p. 89-90). She goes on to say "... behavior and values also are shaped by organizational factors such as opportunities, incentives and the example set by others" (Sharp-Paine, p. 90). Brooke's senior management set the example for the culture of the organization. The focus was on making money and not, apparently, on always behaving with integrity.

Two types of ethics strategies exist: compliance oriented or integrity oriented (Sharp-Paine, p. 91 and 95). Compliance oriented programs focus on legal compliance. Law defines their ethical standards. These companies "rely on rules, controls and strict discipline to maintain standards" (Sharp-Paine, p. 91). On the other hand, integrity oriented companies focus "on self-governance according to guiding principles" (Sharp-Paine, p.93). Companies look at ethics as a "set of values to guide rather than just constrain behavior" (Sharp-Paine, p.93). Companies are not focused just on complying with laws but also with creating an organizational culture that focuses on both being a successful business and on a "set of organizational ideals and responsibilities" and "supporting responsible behavior" (Sharp-Paine, p. 93). It seems apparent, by Brooke's alleged behavior, at most they have focused on compliance with laws and not on creating a culture focusing on integrity.

The business model at Brooke required that all insurance companies pay commissions to Brooke directly and not to the agent. Brooke then withheld any expenses owed by the agent and paid the balance to the agent. However, franchisee agents have complained for several years that Brooke would not send them commission reports from the insurance companies showing the total commissions earned ("Report:Brooke Franchise," 2007). In addition, there were claims that while payments for rent and utilities were withheld from commission checks those payments were not actually made to landlords and utility companies (Dornbrook, 2008, October 24). There are also concerns that Brooke may have left some policyholders without coverage when it held on to premiums instead of sending the payments to insurance companies (Johnson \& Dornbrook, 2008, October 24). Additionally, as Brooke faced financial demise it stopped paying commissions to its franchisee agents and stopped paying rent and utilities (Aldridge, 2009). Franchisee agents were often unable to accurately verifying their pay. In addition, when Brooke did not make payments to landlords, utilities, etc. the franchisee agents were required to double pay in order to keep their business running. This often caused financial hardship. Technically Brooke has not violated any ethics laws; however, they are not creating a culture of integrity.

Several agencies, both federal and state, have investigated Brooke and its activities. In the Fall of 2008 Brooke was being investigated by both the Kansas Insurance Department and the Missouri Department of Insurance. The agencies were investigating the stability of the company and the protection of customers covered by Brooke policies (Kansas Department of Insurance, 2008, Mo. Insurance, 2008). Both agencies were concerned that 
Brooke's lack of payments to insurance companies on behalf of the franchisee agents left clients exposed and without insurance they had paid for.

In December 2008 the FBI, FDIC and SEC all made requests to study Brooke documents (Dornbrook, 2008, December 19). The FBI in particular was investigating the "finances of bankrupt Brooke Corporation" ("FBI Launches Investigation," 2008). Due to the bankruptcy of Brooke, dozens of lenders have been left holding Brooke's bad loans and securities ("FBI Launches Investigation," 2008). These agencies were concerned with the financial integrity of the company. However, while initial investigations were made, no further inquiries have occurred.

These issues are just a few examples of Brooke's behavior. While it appears, based on several investigations, that Brooke is complying with the law it could be argued that they have not focused on integrity. They seem to have focused more on making money and much less on operating with integrity by running a business that was open, transparent, and fair.

\section{LAW IS COMPETING WITH CORPORATE CULTURE}

These laws created to address ethical behavior in companies are butting up against a deep-seeded corporate culture - that of making money. The traditional goal of business has been to make money, to make as much profit as possible. However, the requirements that companies now behave ethically, document their efforts, and provide that information to stakeholders conflicts with those traditional goals. Behaving ethically and making money do not always go hand in hand. Many argue that these laws are too expensive to comply with, are time consuming and some could argue they take the focus away from running a business and put it on compliance with laws. Like many businesses making the news today, Brooke established business practices that focused on making a profit and not necessarily on behaving in an ethical fashion.

Since the adoption of the franchise approach Brooke's general business model has been to generate revenue from franchisee agents. Brooke obtained revenue from its franchisee agents in a number of ways: franchise fees, consulting fees, shares of ongoing revenue and finance charges (Brooke Capital Corp., 2008). The initial franchise fees ranged from $\$ 150,000$ to $\$ 165,000$ regardless of whether the franchisee agent was starting a new office, purchasing an existing location, or converting their agency to a Brooke agency. According to company documents, this fee was to provide franchisee agents with the business model, use of the registered trade name, access to the products of insurance company suppliers, access to the advertising center, facility support and processing center, and use of the internet based information system. For franchisee agents starting a new business a Start-Up Assistance program was available at no additional fee (Brooke Capital Corp., 2008). The purchase price of the franchise was based on a multiple of the target agency's renewable commissions. In addition, there was a $10 \%$ broker fee included in the sales price. Brooke would then finance $90 \%$ with a loan at $3 \%$ above prime with a $3 \%$ loan origination fee. In addition, most franchisee agents were required to purchase the Buyers Assistance Plan. This was priced at 50\% of the previous 12 months of commission.

Brooke subsidiary, Alteritas, provided almost all financing to franchisee agents and other Brooke entities were responsible for valuation and due diligence. Franchisee agents question the level of independence in these transactions and whether proper due diligence was actually performed. Many franchisee agents argue that the ten percent fee paid by the seller is a kickback. More importantly, franchisee agents argue that due to the lack of proper due diligence and valuation services, the purchase prices were incorrectly calculated. Because annual commissions were calculated incorrectly many franchisee agents lost their businesses back to Brooke because the actual sales the agency made were less than promised. That coupled with the overvalued loan made it impossible for the franchise to succeed (Aldridge, 2009).

Once sales of existing agencies slowed, Brooke initiated the Start Up Agency Program. The intention was to add to the franchise network by setting up people in brand new franchise agencies. The concept was sold to potential franchisee agents as a turn-key operation; Brooke would provide an office location, equipment and support staff. In addition, Brooke would provide agents with all necessary insurance company appointments and help them establish customers. Finally, Brooke would provide them with training and advance funds for at least the first six 
months of operation. The required franchise agreement was similar to the agreement signed by existing agents. The franchise fee was in excess of $\$ 150,000$. Brooke provided the financing for the franchise fees and operating expense advances as they did for other franchisee agents. However, the franchisee agents argue that services were never provided as promised (Aldridge, 2009).

Brooke provided insurance consulting services to companies or individuals interested in selling their insurance business. For approximately ten percent of the sales price, Brooke provided valuation and other services (Brooke Capital Corp., 2008). One common business practice was for Brooke to purchase a business from a third party and instantly sell that same business to a franchisee agent. The third party was required to pay Brooke a $10 \%$ consulting fee. The sales price and purchase price were the same this resulted in a ten percent profit for Brooke which was not disclosed to franchisee agents (Aldridge, 2009).

As part of the Franchise Agreement, Brooke was responsible for accounting for premiums and commissions for franchisee agents. Based on Brooke's business model, insurance companies made all commission payments directly to Brooke, not the franchisee agent. After all commissions earned had been accounted for, deductions were made for outstanding loans, franchise fees and other fees or amounts owed. The remaining balance was then paid to franchisee agents. In addition, Brooke received a monthly franchise fee in the form of a percentage of ongoing revenues for each franchise, usually 15\%. An additional share was charged for the optional use of service centers (Brooke Capital Corp., 2008).

Brooke, through Aleritas, loaned cash to franchisee agents to expand or purchase businesses. Brooke then bundled the loans and sold them to lenders. Lenders issued notes to investors, mostly banks. The notes were secured by the income and assets of the franchises. Revenue was "culled" from franchisee agents and placed into trusts that were tapped to pay off the debts (Bank of New York, 2008). This transaction was often done without notice to the franchisee agent.

In August 2008, Brooke entities stopped paying commissions, the primary source of revenue for agents. However, they were still charging franchisee agents for the loans as well as utilities and rent. In October 2008, Special Master Reiderer released the franchisee agents from their Franchise Agreements, but that doesn't clear them from their bank obligations. Some franchisee agents have multiple banks claiming ownership of their loans. In addition, franchisee agents have received eviction notices and had utilities shut off because Brooke has not made payments even though reports show that they did. These franchisee agents have not received the commissions owed to them for several months (Aldridge, 2009).

Brooke was very successful running its business in this fashion. The company was able to bring in funds from a number of sources. However, these business practices were not always beneficial to the franchisee agents. The corporation, as a whole, was quite successful, but often individual franchisee agents struggled to make their businesses successful and pay the required fees to Brooke. Brooke's business practices and actions have caused the financial demise of many franchisees. In addition, some of Brooke's behavior has caused them to become embroiled in several lawsuits.

Several lawsuits have been filed by franchisee agents against Brooke over the past few years with allegations of fraud, embezzlement, etc. Most of the suits relate to the management of funds, business valuations and financing, and repayment of franchisee agent loans ("Suite filed," 2007). BNY, in what appeared to be a foreshadowing of events, predicted correctly when it stated that Brooke faced a revolt from its franchisee agents ("Franchise Terminations," 2008). Dozens of franchisee agents have recently joined together to sue Brooke. Several franchisee agents sued claiming they overpaid for their franchises because the valuations done by Brooke Capital were incorrect ("Suite filed," 2007). In addition, they question the level of independence available when all transactions from valuation through payment were done by Brooke or its subsidiaries ("Suite filed," 2007). Franchisee agents feel that because everything was completed in-house they were not able to verify the accuracy of the numbers or question any of the information provided ("Suite filed," 2007).

In April 2009 dozens of franchisee agents filed a suit against Aleritas involving the sales and financing of franchises (Aldridge, 2009). Many of the issues in this case deal with fairness, independence, and accuracy on 
Brooke's part. The lawsuit alleged that the company "engaged in fraud and civil racketeering". The suit also accused Alteritas of "inflating the price of agencies sold to franchisee agents, receiving kickbacks from the sellers and setup up a system that benefitted from the failure of franchisees" ("Ex-franchiees sue," 2009). It also alleges that Brooke did not provide all "services and benefits promised" to the franchisee agents ("Ex-franchiees sue," 2009). However, in August 2009 a judge dismissed the lawsuit because the "accusations ... were vague and did not meet legal standards to allege fraud and racketeering" ("Judge throws out," 2009).

In November 2009, Robert and Leland Orr were banned from the banking industry for the rest of their lives by the Office of Thrift Supervision. They voluntarily agreed to the prohibition "without admitting or denying that grounds existed" ("Feds ban Brooke," 2009). The order accused the brothers of allowing Brooke companies to become overdrawn at Generations Bank (now Aleritas) without collecting fees or interest charges. The agreement does not ban the Office of Thrift Supervision from further action. In addition, the men could be subject to punishment under federal law. In October, 2008 the OTS declared that Generations Bank (Aleritas) "failed to establish adequate internal controls or to comply with laws related to transactions with affiliates, credit underwriting, and maintenance of records." The OTS ordered Brooke to sell Aleritas by December 15, 2008 and provide a list and description of every transaction that occurred after January involving any affiliate insiders or related interests of insiders ("Brooke Insurance agencies," 2008).

The franchisee agents have argued that, in an attempt to make more money, Brooke treated them unfairly and, on occasion, put them in a position of personal financial risk. In addition, the OTS found that Brooke did not comply with laws by establishing proper internal controls. SOX requires internal controls and proper maintenance of records and all of these laws require ethical and honest behavior, buth they have yet to be raised against Brooke.

\section{AREAS WHERE ADDITIONAL WORK REMAINS FOR SARBANES OXLEY TO ACHIEVE ITS INTENDED IMPACT}

Laws regarding ethical behavior do not create enough of a deterrent to keep companies and employees from continuing current behavior. To-date, these laws have been ineffective because companies are rarely held accountable by them. Many companies have continued behavior that does not comply with laws and continued to profit greatly from that behavior. Even if companies are held liable the financial penalties are not significant enough to eliminate all profits made. Several allegations have been made regarding Brooke and potential illegal activity, but Brooke has yet to be held accountable for its alleged actions under any of these laws. Table 1 is a summary of the sections addressing ethics in the Sarbanes Oxley Act. Brooke's behavior should be evaluated under these sections.

Table 1: Sarbanes-Oxley Act of 2002 (SOX)

\begin{tabular}{|l|l|}
\hline Section 302 & Corporate responsibility for financial statements \\
\hline Section 401 & Disclosures on periodic reports \\
\hline Section 404 & Rules regarding annual reporting \\
\hline Section 805 & Corporate responsibility for financial statements \\
\hline
\end{tabular}

The implementation of SOX has caused companies to evaluate their ethical behavior to ensure compliance. Several key sections of SOX address requirements for ethical behavior, and documentation of those requirements, by companies and their employees.

Section 302 gives corporate responsibility for financial reports. This Section requires that the "principal executive officer or officers and the principal financial officer or officers, or persons performing similar functions, certify in each annual or quarterly report filed or submitted" that the signing officer reviewed the report, that based on that officer's knowledge, the statements contain no fraudulent or misleading information, that the financial statements and other financial information fairly present all material aspects of the financial conditions and results of operation and that the signing officers have disclosed any fraud, material or not, to auditors and the audit committee. Section 401 addresses disclosures in Periodic Reports. This section requires that Pro Forma statements cannot contain fraudulent statements or omissions of material fact which make the statements misleading. Section 404 establishes rules for annual reporting. It places responsibility on management for "establishing and maintaining an 
adequate internal control structure and procedures for financial reporting". Section 805 addresses federal sentencing guidelines for obstruction of justice and extensive criminal fraud. The essence of this section is to ensure that the penalties are high enough to discourage violation of the act. In addition, the Act provides for the enhancement of the offense based on cases where "...the destruction, alteration, or fabrication of evidence involves a large amount of evidence, a large number of participants, or is otherwise extensive ... or the offense involved abuse of a special skill or a position of trust" $(805(\mathrm{a})(2))$. Further guidelines were established to enhance the punishment for a fraud offense that "endangers the solvency or financial security of a substantial number of victims" (805(a)(4)).

Around early to mid 2008 franchisee agents discovered that the loans they had used to finance the purchases of the businesses had been sold, transferred or assigned either all or in portion to third parties without their consent or knowledge even though, under the contracts they signed, consent was required. Until the summer of 2008, franchisee agents continued to receive reports indicating that loan payments were being made to Aleritas. However, it appears that not all the loan payments were being made to the correct parties. These loans are some of the same loans that are at issue in the BNY case (Aldridge, 2009). In September 2008, Aleritas was sued by Bank of New York Mellon for fraud, breach of agreements and misappropriation of funds (Fidler, 2008, October, 31). By October, a Special Master, Mr. Reiderer, was appointed and Trim Creek, an Illinois company, took over 44.3\% control of Brooke's stock (WorldScope, 2009).

Brooke bundled the loans it made to franchisee agents and sold them to investors. The investors then hired an indentured trustee, BNY Mellon, to oversee the loans. BNY was responsible for collecting funds and controlling collateral. The collateral for the notes were virtually all of Brooke's assets including loans, other assets, special trust accounts, bank accounts and lock-boxes. Many of the loans included were loans made by Aleritas to insurance agents or agencies. The claim is that Brooke diverted funds from the Trusts into its own accounts through a bank it owns, Brooke Savings Bank, instead of properly funding the accounts and paying back the investors (Bank of New York, 2008).

The process established to collect funds was fairly complicated and was quite advantageous to Brooke. All funds, including commissions, were to be swept on a daily basis to a master account. This account was to be the main repository for all funds. Textron Business Services (TBS) was hired to maintain the asset pools; however, TBS then delegated those responsibilities back to Aleritas and Brooke Capital. In this role both Aleritas and Brooke Capital accumulated information and records regarding the status of Brooke Loans. Aleritas continued to provide financing services to franchisee agents. Brooke Capital continued to provide marketing services to franchisee agents. Through this delegation Brooke Capital and Aleritas were able to manage the reporting of the very assets they were to maintain as collateral (Bank of New York, 2008).

BNY has leveled several allegations against Brooke regarding the handling of of funds to be deposited in the master account. The most serious allegation is that Brooke misappropriated funds by failing to put all funds into the master account and by selling assets without authorization. BNY has also accused Brooke of altering computer systems to "conceal information regarding banks accounts and deposits made" so that it was difficult to find the money (Bank of New York, 2008).

Disbursements were made to investors based on the information provided by Brooke and the funds in the master account. BNY believes that Brooke falsified its financial reports in order to conceal the "misappropriation and misdirection of funds" (Bank of New York, 2008). In addition, BNY believes that Robert Orr directed the actions to alter the financial statements. BNY claims that Mr. Robert Orr directed BASC and Brooke Capital sales teams to continue depositing funds in the wrong accounts. Since the agreement, proceeds from the sales of an agency and insurance commissions have continued to be diverted to an account at Brooke Savings Bank. According to an employee email dated August 26, 2008 this was all done at the direction of Robert Orr (Bank of New York, 2008, Brooke Capital Comments, 2009). However, some of the parties to the lawsuit entered into an agreement. As part of that agreement Brooke agreed to pay all funds to the correct accounts.

The latest case involving Brooke was filed in June 2009. Albert Reiderer, the bankruptcy trustee for Brooke, sued to block bankruptcy protection sought by Robert Orr ("Brooke Corp. trustee," 2009). Mr. Orr filed personal bankruptcy in December 2008. As part of the bankruptcy he sought to protect himself from repaying debts 
he owed to Brooke Corporation, Brooke Capital, and Brooke Investments (Riederer, 2009). The suit alleged that Mr. Orr "transferred \$4million from various Brooke accounts to Brooke Holdings. The suit alleges that money that was supposed to be captured on franchisee agent debt was, instead, diverted by Mr. Orr to Brooke Holdings. It appears that Mr. Orr intended the money go to his family. Mr. Riederer claims Mr. Orr did this "at a time when he knew that the Brooke companies would be unable to sustain their business operations for any significant period of time" ("Brooke Corp. trustee," 2009). In addition, the suit alleges that Mr. Orr transferred \$14million to cover the debt of franchisee agents in order to hide the true financial condition of the company ("Brooke Corp. trustee," 2009). Finally, the suit alleges that he directed the diversion of another $\$ 4$ million to cover an overdraft that the Brooke companies had at Generations Bank ("Brooke Corp. trustee," 2009).

The BNY case, and the Orr case show Brooke's failure to comply under Section 302. The BNY case may seem more obvious as one of the allegations clearly made is the case is that Brooke and its senior management knowingly manipulated financial statements. In addition, Mr. Orr could be liable in his own case if he did, indeed, misappropriate funds from the company as he would be signing financial statements knowing that they are false because he has taken funds from the company. In both the BNY case and franchisee agent case there were allegations of fraud. These allegations have been leveled at senior management of Brooke. Therefore, the senior management couldn't comply with the requirements under this section and sign the financial statements because they not only knew of the fraud, but caused it to happen.

Section 404 is where Brooke could most obviously be held liable. SOX requires adequate control structures for financial reporting. The franchisee agent case looks at both the reporting of commissions, payments and loans and the valuation of agencies purchased and sold. If proper financial reporting procedures had been in place neither of these issues could have arisen. The BNY case deals with financial reporting at a higher level as it looks at the manipulations of the actual financial statements. However, like the franchisee agent case, had the proper controls and procedures been in place these issues would never have arisen. The same can be said for the case against Mr. Orr. If proper procedures had been in place he would never have been in a position where he could successfully direct two different fund diversions. In addition, if proper procedures had been in place those diversions would have been caught and reported from internal, not external, sources.

Section 805 of SOX looks to ensure that penalties are severe enough to discourage misbehavior. Here punishment can be enhanced based on the severity of behavior. Looking at the franchisee agent case, Brooke could be facing a number of issues. First, they were in a position of special skill or trust. Franchisee agents relied on Brooke, because there were required to, for everything from business valuation and financing to accounting and support functions. They put themselves in a position of trust because there forced franchisee agents to rely on them so heavily. Second, the actions of Brooke threatened its own solvency and the solvency of its franchisee agents. By not properly completing due diligence or properly valuing businesses Brooke put franchisee agents in positions where they could not succeed. With the failure of so many franchisee agents came the failure of the whole organization.

The BNY case deals with another part of Section 805, the "destructions, alteration, or fabrication" of records. BNY alleges that Brooke manipulated both financial records and computer records. By doing so, Brooke was attempting to hide the money it had misappropriated by making it nearly impossible to figure out where the money had been moved. Because this money was hidden, agencies weren't paid commissions, utilities weren't paid, rent wasn't paid. All of this caused financial failure for several franchisee agents, the victims of this situation.

There are several allegations that Brooke financial statements have been falsified. The $B N Y$ case alleges that Brooke and its management falsified records in order to hide the misappropriation of funds owed to BNY. In addition, the trustee suit against Mr. Orr argues that he personally ordered such actions. The BNY case backs this up by saying that Mr. Orr not only knew about the falsification, but "caused and directed" (Bank of New York, 2008) others to commit these acts. However, regardless of how it appears, Brooke and its management have not had SOX raised against them. In all of the suits and investigations SOX has not once been raised. 


\section{WHAT WORK REMAINS TO BE DONE WITH OTHER LAWS}

In addition to Sarbanes Oxley, several other laws address ethical expectations of companies and their employees, as shown in Table 2.

Table 2: Additional Ethics Laws

\begin{tabular}{|l|l|}
\hline Securities Exchange Act of $\mathbf{1 9 3 4}$ & \\
\hline Section 18 & Willful violations through false and misleading statements \\
\hline Section 32 & Personal liability for willful violations \\
\hline Section 32(a) & False or misleading statements relied on in purchase or sale \\
\hline Sentencing Commission Guidelines & Scoring factors for punishment \\
\hline
\end{tabular}

\section{SECURITIES EXCHANGE ACT OF 1934}

The Securities Exchange Act of 1934 contains several sections addressing the ethical behavior of organizations. Section 32 deals with willful violations through false and misleading statements. Under this section any person who "willfully and knowingly makes, or causes to be made, any statement in any application, report, or document required to be filed under this title ... which statement was false or misleading with respect to any material fact, shall upon conviction" fined up to $\$ 5$ million, put in prison up to 20 years or both. However, when that "person" is a corporation the fine increase to $\$ 25$ million. Of course, because it is a corporation, no prison time is feasible.

In addition, individuals within a corporation can be held personally liable for their actions. Section 32(a) states that "[a]ny officer, director, employee, or agent of an issuer, or stockholder acting on behalf of such issuer, who willfully violates" the law will pay fines up to $\$ 100,000$ and spend up to five years in prison. In addition, the Commission could bring a civil action against the individual with a maximum penalty of $\$ 10,000$.

Section 18 of the Securities Exchange Act of 1934 punishes those who "make false or misleading" statements with regard to a material fact that someone relies on in purchasing or selling a security. Individuals will be liable for the damages caused.

\section{UNITED STATES SENTENCING COMMISSION}

The United States Sentencing Commission (2004) guidelines have recently been revised. Under the new guidelines organizations are scored based on six factors. This score is used by the sentencing court when considering punishment. Four of the factors can increase the punishment rendered and two factors can mitigate the punishment. Those factors that can increase punishment are: involvement or tolerance of criminal activity, prior history of the organization, violations of an order, or obstruction of justice (United States Sentencing Commission, p. 491). The factors that can mitigate punishment are: existence of an effective compliance and ethics program and self-reporting, cooperation, or acceptance of responsibility (p.491). The mere existence of the two mitigating factors is not enough, under the new guidelines, to reduce culpability. "[T] organization will not be eligible to receive a downward adjustment for having an ECEP if the organization delays reporting an offense and/or if individuals within certain levels of the organization "participated in, condoned or were willfully ignorant of the offense"' (Association of Corporate Counsel, p. 7). The New Guidelines also establish rebuttable presumptions that no ECEP exists if individuals within certain positions at an organization or a small organization "participated in, condoned or [were] willfully ignorant of the offense" (p.7-8).

Under the Securities and Exchange Act of 1934 Brooke, as an organization, and Mr. Orr, individually, are potentially liable. In addition, those officers, directors, employees or agents who committed the acts could also be held liable. Section 32 deals with the corporation and individuals who knowingly cause such misrepresentations to be made. Here, both Brooke and Mr. Orr could be found liable for misrepresentations. Mr. Orr not only knew that the financial statements were being falsified, but he also allegedly ordered that the falsifications be made. 
Section 32(a) of the Securities and Exchange Act of 1934 deals with those individuals who actually made the falsifications under somebody's direction. These individuals will be held personally liable if they "willfully" violated the Act. Further investigation will have to be made into the actions of the individuals. However, the August email of one employee demonstrates some unwillingness to participate in these actions. On August 27, 2008 an employee at Aleritas sent an email to several top company executives asking why proceeds from one loan were being sent to an entity that wasn't involved in the loan payoff process. Vice President Mick Lowry responded that misapplication of the proceeds was a confidential and internal matter. He said he was following instructions from Aleritas' CEO.

Under Section 18 arguably there are several instances where Mr. Orr and other members of senior management could be found liable. The stock was sold on an open exchange. Mr. Orr and others made statements regarding the health of the company and signed off on financial statements for the organization that they knew to be false. All of these could easily be used in making purchase or sale decisions for a company's stock.

Federal sentencing guidelines were established to encourage businesses to operate in an ethical manner. In this case, based on the behavior of Brooke and its senior management it seems unlikely that punishment could be mitigated. First, the guidelines indicate that punishment will not be mitigated for individuals within certain levels of the organizations who "participated in, condoned, or were willfully ignorant of the offense". Mr. Orr's actions certainly fit this definition. According to the allegations made, Mr. Orr not only knew of the inappropriate actions being taken, but at least in the case of the misappropriating funds, he directed those actions.

Second, at this point there does not appear to be "self-reporting, cooperation or acceptance of responsibility". Mr. Orr and other management admit to withholding funds from BNY yet they argue they were justified in such actions. As far as the issues with the franchisee agents there has yet to be acceptance of responsibility. Not only that, but to-date, Brooke and its affiliates have hidden behind the arbitration clauses written into franchisee contracts to avoid having to publicly admit wrongdoing.

It could be argued that Brooke and some of its executives have violated the laws of the Securities Exchange Act of 1934 and the Federal Sentencing Guidelines. However, these laws have not been raised against Brooke or any of its executives. These laws as they are enforced today are not enough of a deterrent. A law can only be a deterrent if it is properly and consistently enforced. Until that is done these laws will remain ineffective.

\section{CONCLUSION}

Brooke hasn't made big headlines for their potential violation of these laws. As a matter of fact, these laws, though clearly applicable, have not been raised against Brooke or any of its management. Regardless how much media coverage this case has received, the failure of Brooke has had a substantial impact. Several hundred franchisee agents have lost their businesses and livelihoods. Many of the franchisee agents are in financial ruin, having to file for bankruptcy and receiving negative credit reports because Brooke failed to pay rent, utilities, and loans even though franchisee agents had been charged.

What seems more disturbing is that these laws seem to have failed to do what they set out to do. It would be a sad consequence that so many franchisee agents lost their businesses, but it could be vindication had Brooke been found liable under any of these laws. Not only has Brooke not been found liable, but also these laws have not been raised against Brooke. In all the lawsuits and investigations, not one has raised an issue of ethics. It seems hard to imagine that any company or its executives would feel threatened by imprisonment and fines if the law is never enforced. The only hope these laws have of becoming effective is if they are actively enforced against companies and their management.

Biography

\section{AUTHOR INFORMATION}

Beth Hazels has experience teaching in business law, communications and management. In addition, she has ten years experience in management consulting and internal audit. 


\section{REFERENCES}

1. Aldridge v. Aleritas Capital Corp., No. 09-CV-2178 CM/KGS (D. Kan filed April 8, 2009).

2. Association of Corporate Counsel (2005). The New Federal Sentencing Guidelines for Organizations: Great for Prosecutors, Tough on Organizations, Deadly for the Privilege.

3. Bank of New York v. Aleritas Capital Corp., No. 08-CV-2424 JWL /DJW, 2008 U.S. Dist. LEXIS 70705, (D. Kan. Sept. 17, 2008).

4. Brooke Capital Comments on Lawsuit. Retrieved January 20, 2009 from Brooke Insurance Website: http://www.brookeagent.com/lawsuit_comments.html.

5. Brooke Capital Corp. (2008). SEC From 10-K for the Year Ended December 31, 2007. Retrieved from Lexis-Nexis Academic database.

6. Brooke Corp. trustee sues to block Orr bankruptcy. (2009, June 19). Kansas City Business Journal. Retrieved from http://kansascity.bizjournals.com/kansascity.

7. Brooke Insurance agencies find potential buyers. (2008, October 28). Kansas City Business Journal. Retrieved from http://www.bizjournals.com/kansascity.

8. Dornbrook, J. (2008, October 10). Bank forces Brooke founder to sell his holdings. Kansas City Business Journal. Retrieved from http://kansascity.bizjournals.com.

9. Dornbrook. J. (2008, October 24). Brooke agents claim mistreatment. Kansas City Business Journal. Retrieved from http://www.bizjournals.com/kansascity.

10. Dornbrook, J. (2208, December 19). Investigators begin circling Brooke units. Kansas City Business Journal. Retrieved from http://www.kansascity.bizjournals.com/kansascity.

11. Everitt, J. (2007, August 28). BXXX: To List on AMEX and Trade Under BCP symbol. Retrieved from http://www.knobias.com.

12. Ex-franchisees sue Brooke Corp. unit for fraud, racketeering. (2009, April 9). Kansas City Business Journal. Retrieved from http://kansascity.bizjournals.com/kansascity.

13. FBI Launches Investigation of Bankrupt Brooke Corp. (2008, December 15). Insurance Journal. Retrieved from http://www.insurancejournal.com/news/midwest.

14. Feds ban Brooke Corp. founders from banking for life. (2009, November 23). Kansas City Business Journal. Retrieved from http://www.bizjournals.com/kansascity.

15. Fidler, B. (2008, October 30). Financial mess drives Brooke into Ch. 11. Retrieved February 23, 2009 from http://thedeal.com.

16. Fidler, B. (2008, October 31). Brooke gets Ch. 11 trustee. Retrieved February 23, 2009 from http://thedeal.com.

17. Franchise Terminations. (2008, November 19). Retrieved from Brooke Insurance website http://www.brookeagent.com.

18. Johnson, K. and Dornbrook, J. (2008, October 24). All but a few local Brooke insurance agencies close. Sacramento Business Journal. Retrieved from http://www.bizjournals.com/sacramento.

19. Judge throws out suit against Brooke unit. (2009, August 13). Kansas City Business Journal. Retrieved from http://kansascity.bizjournals.com/kansascity.

20. Kansas Department of Insurance (2008, September 16). Legal issues of Kansas company on insurance department's radar. Retrieved from http://www.ksinsurance.org.

21. Margolies, D. (2009, January 10). Insurance agents learn tough lessons from Brooke Corp. The Kansas City Star. Retrieved from http://infoweb.newsbank.com.

22. Margolies, D. (2009, February 14). Bankruptcy judge approves settlement in Brooke commissions. The Kansas City Star. Retrieved from http://www.infoweb.newsbank.com.

23. McGraw-Hill Companies, Inc. (2009). Standard and Poor's Corporate Descriptions Plus News: Brooke Corp. Retrieved February 23, 2009 from Lexis-Nexis Academic database.

24. Mo. Insurance department probing Brooke Corp. (2008, November 3). St. Louis Business Journal. Retrieved from http://www.bizjournals.com/stlouis.

25. Riederer v. Orr, No. 08-13242 (D. Kan. Filed June 10, 2009).

26. Report: Brooke Franchise Corporation, Brook Credit. (2007, January 30). Retrieved January 20, 2009 from http://www.ripoffreport.com/reports.

27. Sarbanes-Oxley Act of 2002, Pub. L. No. 107-204, 116 Stat. 745 (codified in scattered sections of 15 U.S.C.). 
28. Securities Exchange Act of 1934. C.404, Title I, §18, 48 Stat. 897 (1936).

29. Securities Exchange Act of 1934. C.404, Title I, §32, 48 Stat. 904 (1934).

30. Suit filed against Brooke Franchising. (2007, September 25). Insurance Journal. Retrieved from http://www.insurancejournal.com/forums.

31. Trading halted on Brooke stocks. (2008, October 27). Sacramento Business Journal. Retrieved from http://www.bizjournals.com/sacramento.

32. United States Sentencing Commission (2004). Chapter 8 - Sentencing of Organizations.

33. Worldscope (2009). Brooke Corporation. Retrieved February 23, 2009 from Lexis-Nexis Academic database.

\section{NOTES}


Journal of Business Case Studies - November/December 2010

Volume 6, Number 6

NOTES 